RESEARCH REPORT

\title{
Psychosocial and physical work environment, and risk of pelvic pain in pregnancy. A study within the Danish national birth cohort
}

\author{
Mette Juhl, Per Kragh Andersen, Jørn Olsen, Anne-Marie Nybo Andersen
}

J Epidemiol Community Health 2005;59:580-585. doi: 10.1136/jech.2004.029520

See end of article for authors' affiliations

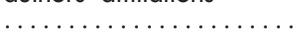

Correspondence to: Ms M Juhl, National Institute of Public Health, 5, Øster Farimagsgade, DK1399 Copenhagen K Denmark; mju@niph.dk

Accepted for publication 27 January 2005

Objective: The sparse knowledge of the aetiology of pelvic pain in pregnancy makes evidence based prevention a limited option. The aim of this study was to examine the relation between pelvic pain in pregnancy and physical and psychosocial working conditions.

Methods: This study used self reported data on working conditions for 1219 cases and 1539 controls, sampled as a nested case-control study within the Danish national birth cohort. Cases and controls were selected on the basis of self reported pelvic pain intensity, pain localisation, and pain impact on daily living activities. Exposure data were collected prospectively; early in pregnancy and before the onset of pelvic pain. Main outcome measures were odds ratios for pelvic pain in pregnancy as a function of physical and psychosocial working conditions.

Results: Pregnant women with fixed evening work and with rotating shifts (without night shift) had odds ratios for pelvic pain in pregnancy of 1.76 (95\% confidence intervals 1.04 to 2.96$)$ and 1.65 (1.22 to $2.24)$, respectively, compared with women with day work. Physically strenuous work was associated with an almost $50 \%$ increased risk of pelvic pain in pregnancy $(1.47 ; 1.17$ to 1.84$)$. In women who were under high psychosocial strain at work odds ratio was 1.39 (1.12 to 1.74) compared with women with low job strain.

Conclusion: Both physically and psychosocially demanding working conditions, measured by physically strenuous work, rotating shifts, and high job strain, are associated with an increased reporting of pelvic pain in pregnancy.

$\mathrm{P}$ elvic pain is a common ailment during pregnancy, ${ }^{1}$ and some women suffer from pain and/or pelvic instability during pregnancy and/or puerperium to an extent that it affects their ability to carry out daily activities, for example, walking. ${ }^{2-4}$ This condition has been entitled symptom giving pelvic girdle relaxation (in the following termed as "pelvic pain"). The diagnostic criteria are, however, not precise and neither is the aetiology. Symptoms are pain around the pelvic joints. Pain can occur at all levels from discomfort to complete immobilisation. ${ }^{2}{ }^{3}$

The reported incidence of pelvic pain varies substantially in the literature from $2 \%$ to $42 \%$ of all pregnant women..$^{5-13} \mathrm{~A}$ lack of distinct diagnostic criteria is probably the main reason for this variation, as the diagnosis predominantly relies on subjective pain reporting. ${ }^{4{ }^{6}{ }^{14-16}}$ Evaluations of clinical tests show that the women's answers to pain provocation tests are more reliable than the judgment of palpation made by skilled examiners. $^{8}$ Onset is most frequent between third and seventh month of pregnancy ${ }^{16}$ and $9 \%$ of women with pelvic pain during pregnancy still suffer from pelvic joint pain two years after childbirth. ${ }^{17}$ Pelvic pain is one of the most commonly used indicators in Denmark for sick absence during pregnancy (one third of pregnancy related sick leave days). ${ }^{11}{ }^{18-20}$ It is a neglected condition of substantial public health impact.

A softening of the pelvic joints is one of many physiological changes during pregnancy, and could seem an obvious biological cause of the condition, but the reason why some women experience severe pain is still unknown. Relaxin, a peptide hormone, is involved in the softening of the pelvic joints and may have a part for pelvic pain. Studies on serelaxin and pelvic pain have, however, showed conflicting results. ${ }^{21-25}$
The incidence of pelvic pain has been found to be similar in Scandinavia and Africa in both rural and non-rural areas, ${ }^{26}$ and identification of risk factors related to working conditions could lead to a better understanding of the nature of the condition and may suggest preventive measures. A Danish cohort study found increased risk of pelvic pain in women working in draught and cold or with uncomfortable working postures. ${ }^{11}$ Frequent twisting and bending or forward body bending have also been suggested associated with the condition, ${ }^{9}$ and both physical and psychosocial work stressors are associated with other types of musculoskeletal pain disorders. ${ }^{27-30}$ High occupational demands combined with low decision latitude are known to be predictive for the development of several types of diseases correlating with stress hormones. ${ }^{31} 32$

The aim of this study was to examine the relation between both physical and psychosocial working conditions and the reporting of pelvic pain during pregnancy or shortly after delivery.

\section{METHODS}

The background cohort study

From 1997 to 2003 women were recruited to the Danish national birth cohort, a nationwide study of 100000 pregnant women and their offspring. Our study on pelvic pain in pregnancy was carried out as a case-control study within this birth cohort. Pregnant women in Denmark were invited to the birth cohort study by their general practitioner and were included when the study centre had registered a signed informed consent form. In the birth cohort study the women took part in four telephone interviews: (1) in 12th16th pregnancy week, (2) in 30th pregnancy week, (3) six months after childbirth, and (4) 18 months after childbirth. 
Questions:

Figure 1 Case definition according to the questions asked in the interview.

1) Self reported pelvic pain (screening question, addressed to all during the time of recruitment) "Did you feel pelvic pain to an extent that affected your ability to walk, during pregnancy or shortly after delivery?"

2) Pain localisation (posed to those who responded yes to question 1) "Where did you feel pain?"

3) Pain level in five daily functions (diagnostic questions, here put into one, posed to cases and controls) "Did you feel pain when turning over in bed, ...when walking, ... when getting up from a dining room chair, ... when getting up from a sofa, ...when walking on stairs?" (no pain, some pain, strong pain)

\begin{tabular}{|c|}
\hline $\begin{array}{l}\text { Mild cases: } \\
\text { - Yes in question } 1 \\
\text { - Pain localised around the symphysis or in the low back } \\
\text { region from hip or below (question 2) } \\
\text { - Some pain in at least one of the daily functions (question 3) } \\
\text { and/or strong pain in not more than one of the functions }\end{array}$ \\
\hline $\begin{array}{l}\text { Severe cases: } \\
\text { - Yes in question } 1 \\
\text { - Pain localised around the symphysis or in the low back } \\
\text { region from hip or below (question 2) } \\
\text { - Some or strong pain in at least two of the daily functions (question 3) }\end{array}$ \\
\hline
\end{tabular}

About $60 \%$ of all eligible women received information on the study (based upon the degree of collaboration from the general practitioners and the midwives). Except for two counties about $35 \%$ of all pregnant women were recruited for the study, thus it is estimated that about $60 \%$ of those invited participated in the study. Details about the Danish national birth cohort are presented elsewhere. ${ }^{33}$

Based on sample size calculations we aimed at including 1500 cases and 1500 controls. At the time of recruitment to the birth cohort we expected 20000 women per year to complete the third interview, and we expected an end point incidence of $10 \%$. As only $75 \%$ of the potential cases were expected to fulfil the final inclusion criteria, a one year period of recruitment for the pelvic pain study was scheduled. However, the actual inclusion rate to the birth cohort was lower and consequently recruitment was extended to cover the period from April 2000 to November 2001 during which 15972 women completed the third interview.

\section{Selection of cases and controls and measurement of outcome}

A screening question in the third interview was used to identify potential cases for the pelvic pain study (fig l, question 1). Controls were selected among all women who took part in this interview during a five week period and who responded negatively to the screening question; 2486 potential cases and 2340 potential controls were identified this way. The selection of controls was split up into five single weeks spread equally over the data collecting period to avoid any climatic influence. Exposure data were collected in the first interview, so only women who had completed both the first and the third interview were included. Thus, we selected for further analysis the 2215 potential cases (89\%) and 2082 potential controls $(89 \%)$ who had completed both interviews.
All potential cases were asked about specific pain localisation in the third interview (fig 1, question 2) and 549 were excluded because they reported pain located outside the pelvic area. Furthermore, all women, irrespective of their answer to the screening question, were asked about pain intensity when performing daily functions (fig 1, question 3 ). For the remaining 1666 potential cases, 44 reported no pain in any of the five daily functions (fig 1, question 3 ) and were therefore excluded. Furthermore, cases were categorised into mild (523) and severe (1099), see figure 1. Our definition of severe cases corresponds closely to the one used by Larsen et al. ${ }^{11}$ Based on the pain intensity question 6\% (115) of the 2082 potential controls were excluded because they reported pain levels equivalent to the severe case group, leaving 1622 cases and 1967 controls in the study.

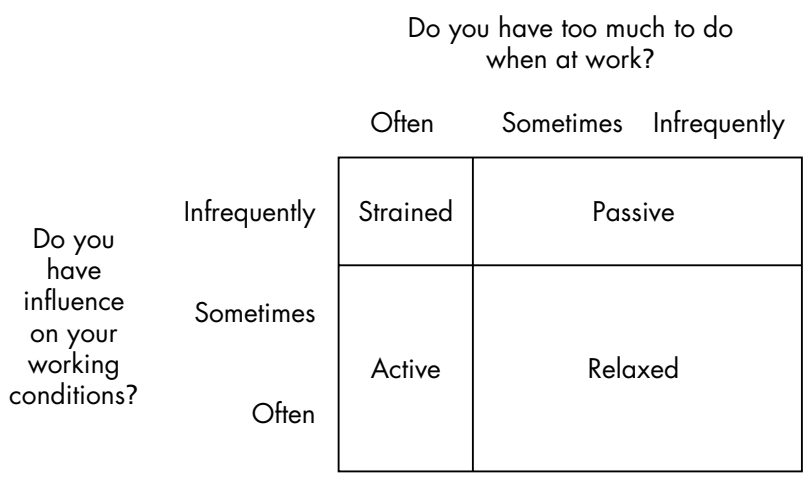

Figure 2 Graphic illustration to show how job strain categories were constructed. 


\section{Measurement of exposure}

Data on exposures were collected from the first interview. If a woman worked a minimum of 15 hours per week at the time of this interview or had been doing so within three months before, she would be asked about occupational exposures. Data on physical working conditions were obtained from the following variables: job status (job title, classified from the Danish version of The International Standard Classification of Occupations, DISCO-88), number of working hours per week, working posture (predominantly sitting, predominantly standing or walking, or a mixture of the three), working hours (day, evening, night, rotating without night, rotating with night), daily work related carrying of heavy burdens (no, 11-20 kilos, >20 kilos), and physically strenuous work in general (often, some times, infrequently).

The job strain model is constructed on the basis of demand and control levels in working life and it combines information on these two parameters into four categories: relaxed, passive, active, and strained. "Relaxed" refers to low job strain and "strained" refers to high job strain. ${ }^{31}{ }^{32}$ Demands were measured by the following question in the first interview: "Do you have too much to do when at work?" (often, some times, infrequently), and control was measured by the question: "Do you have influence on your working conditions?" (often, some times, infrequently). High demands were defined a priori by the answer "often" to make the high strain category as strained as possible (see fig 2). Similarly, low control was defined by the answer "infrequently". Information on social support was obtained from the question: "Do you receive help from your colleagues when you have problems at work?".

The following possible confounding factors were chosen from the literature and collected from the first interview: age, parity, pre-pregnant BMI, previous low back pain, smoking, and psychiatric illnesses. Data on previous pelvic pain were available from the third interview.

\section{Statistical analysis}

Associations were analysed by means of logistic regression using both the restricted (severe) case group and the entire

Table 1 Numbers and percentages of severe cases, mild cases, and controls according to physical working conditions and job strain, and to overall working status

\begin{tabular}{|c|c|c|c|c|c|c|c|}
\hline \multirow[b]{2}{*}{ Variables } & \multirow[b]{2}{*}{ Value } & \multicolumn{2}{|c|}{ Severe cases } & \multicolumn{2}{|c|}{ Mild cases } & \multicolumn{2}{|l|}{ Controls } \\
\hline & & Number & $\%$ & Number & $\%$ & Number & $\%$ \\
\hline \multicolumn{8}{|l|}{ Women in work ${ }^{*}(n=2758)$} \\
\hline \multirow[t]{5}{*}{ Job status } & in executive jobs or jobs & 125 & 16 & 96 & 24 & 311 & 20 \\
\hline & in jobs requiring middle & 268 & 33 & 131 & 32 & 531 & 35 \\
\hline & in the office or welfare area & 344 & 43 & 156 & 38 & 582 & 38 \\
\hline & in skilled or unskilled jobs & 70 & 9 & 24 & 6 & 108 & 7 \\
\hline & missing & 3 & 0 & 2 & 1 & 7 & 1 \\
\hline \multirow[t]{5}{*}{ Working hours } & day & 611 & 75 & 311 & 76 & 1278 & 83 \\
\hline & evening & 28 & 4 & 17 & 4 & 31 & 2 \\
\hline & night & 15 & 2 & 6 & 2 & 16 & 1 \\
\hline & rotating shiffs (without night) & 87 & 11 & 33 & 8 & 103 & 7 \\
\hline & rotating shifts (with night) & 69 & 9 & 42 & 10 & 111 & 7 \\
\hline \multirow{4}{*}{$\begin{array}{l}\text { Number of working } \\
\text { hours per week }\end{array}$} & $15-30$ & 140 & 17 & 80 & 20 & 278 & 18 \\
\hline & $31-37$ & 580 & 72 & 283 & 70 & 1062 & 69 \\
\hline & $>37$ & 88 & 11 & 44 & 11 & 197 & 13 \\
\hline & missing & 2 & 0 & 2 & 1 & 2 & 0 \\
\hline \multirow[t]{4}{*}{ Working posture } & predominantly sitting & 158 & 20 & 87 & 21 & 385 & 25 \\
\hline & $\begin{array}{l}\text { predominantly standing or } \\
\text { walking }\end{array}$ & 239 & 30 & 129 & 32 & 353 & 23 \\
\hline & a mixture of the three & 410 & 51 & 192 & 47 & 799 & 52 \\
\hline & misssing & 3 & 0 & 1 & 0 & 2 & 0 \\
\hline \multirow{4}{*}{$\begin{array}{l}\text { Daily work related carrying } \\
\text { of heavy burdens }\end{array}$} & no & 501 & 62 & 245 & 60 & 1115 & 72 \\
\hline & yes, $11-20$ kilos & 143 & 18 & 88 & 22 & 232 & 15 \\
\hline & yes, $>20$ kilos & 163 & 20 & 75 & 18 & 188 & 12 \\
\hline & missing & 3 & 0 & 1 & 0 & 4 & 0 \\
\hline \multirow[t]{3}{*}{ Physically strenuous work } & sometimes or infrequently & 558 & 69 & 309 & 76 & 1272 & 83 \\
\hline & often & 252 & 31 & 100 & 24 & 265 & 17 \\
\hline & missing & 0 & 0 & 0 & 0 & 2 & 0 \\
\hline \multirow[t]{5}{*}{ Job strain† } & relaxed & 274 & 34 & 136 & 33 & 639 & 42 \\
\hline & passive & 238 & 29 & 122 & 30 & 460 & 30 \\
\hline & active & 96 & 12 & 55 & 13 & 166 & 11 \\
\hline & strained & 201 & 25 & 93 & 23 & 272 & 18 \\
\hline & missing & 1 & 0 & 3 & 1 & 2 & 0 \\
\hline \multirow{3}{*}{\multicolumn{2}{|c|}{$\begin{array}{l}\text { Women, working } \\
\text { Women, not working } \\
\text { All women } \mathbf{n}=\mathbf{3 5 8 9}\end{array}$}} & 810 & 100 & 409 & 100 & 1539 & 100 \\
\hline & & $289 \ddagger$ & & 114 & & $428 \ddagger$ & \\
\hline & & 1099 & & 523 & & 1967 & \\
\hline
\end{tabular}

*Includes women working a minimum of 15 hours per week at the time of the interview or within three months before the interview. Students with same working pattern are also included. †Job strain categories: relaxed, low demands and high control; passive, low demands and low control; active, high demands and high control; strained, high demands and low control. \#lncludes one missing. 
Table 2 Odds ratios for pelvic pain in pregnancy according to physical working conditions and job strain. Severe and mild cases analysed together. Only women in work $(n=2758)$

\begin{tabular}{|c|c|c|c|c|}
\hline Exposure variables & Value & Crude OR & Adjusted $\mathrm{OR}^{*}$ & $95 \% \mathrm{Cl}$ \\
\hline Job status & $\begin{array}{l}\text { in executive jobs or jobs requiring higher education } \\
\text { in jobs requiring middle range education } \\
\text { in the office or welfare area or self employed } \\
\text { in skilled or unskilled jobs }\end{array}$ & $\begin{array}{l}1 \\
1.06 \\
1.21 \\
1.22\end{array}$ & $\begin{array}{l}1 \\
0.87 \\
1.00 \\
0.86\end{array}$ & $\begin{array}{l}-\overline{0} \\
0.69 \text { to } 1.10 \\
0.80 \text { to } 1.25 \\
0.60 \text { to } 1.23\end{array}$ \\
\hline Working hours & $\begin{array}{l}\text { day } \\
\text { evening } \\
\text { night } \\
\text { rotating shifts (without night) } \\
\text { rotating shifts (with night) }\end{array}$ & $\begin{array}{l}1 \\
2.01 \\
1.82 \\
1.61 \\
1.39\end{array}$ & $\begin{array}{l}1 \\
1.76 \\
1.36 \\
1.65 \\
1.34\end{array}$ & $\begin{array}{l}- \\
1.04 \text { to } 2.96 \\
0.66 \text { to } 2.82 \\
1.22 \text { to } 2.24 \\
0.99 \text { to } 1.87\end{array}$ \\
\hline Number of working hours per week & $\begin{array}{l}15-30 \\
31-37 \\
>37\end{array}$ & $\begin{array}{l}1 \\
1.03 \\
0.85\end{array}$ & $\begin{array}{l}1 \\
1.12 \\
0.87\end{array}$ & $\begin{array}{l}-\overline{0} \\
0.61 \text { to } 1.38 \\
0.64 \text { to } 1.17\end{array}$ \\
\hline Working posture & $\begin{array}{l}\text { predominantly sitting } \\
\text { predominantly standing or walking } \\
\text { a mixture of the three }\end{array}$ & $\begin{array}{l}1 \\
1.64 \\
1.18\end{array}$ & $\begin{array}{l}1 \\
1.04 \\
1.02\end{array}$ & $\begin{array}{l}- \\
0.80 \text { to } 1.35 \\
0.83 \text { to } 1.25\end{array}$ \\
\hline Daily work related carrying of heavy burdens & $\begin{array}{l}\text { no } \\
\text { yes, } 11-20 \text { kilos } \\
\text { yes, }>20 \text { kilos }\end{array}$ & $\begin{array}{l}1 \\
1.49 \\
1.89\end{array}$ & $\begin{array}{l}1 \\
1.12 \\
1.14\end{array}$ & $\begin{array}{l}- \\
0.88 \text { to } 1.44 \\
0.86 \text { to } 1.50\end{array}$ \\
\hline Physically strenuous work & $\begin{array}{l}\text { sometimes or infrequently } \\
\text { often }\end{array}$ & $\begin{array}{l}1 \\
1.95\end{array}$ & $\begin{array}{l}1 \\
1.47\end{array}$ & $\overline{1.17}$ to 1.84 \\
\hline Job strain $†$ & $\begin{array}{l}\text { relaxed } \\
\text { passive } \\
\text { active } \\
\text { strained }\end{array}$ & $\begin{array}{l}1 \\
1.22 \\
1.42 \\
1.68\end{array}$ & $\begin{array}{l}1 \\
1.11 \\
1.32 \\
1.39\end{array}$ & $\begin{array}{l}- \\
0.92 \text { to } 1.35 \\
1.02 \text { to } 1.71 \\
1.12 \text { to } 1.74\end{array}$ \\
\hline
\end{tabular}

*Exposure variables mutually adjusted and adjusted for confounders that changed the fully adjusted estimates $>5 \%$. Working hours adjusted for previous pelvic pain. Work related carrying of heavy burdens adjusted for previous pelvic pain and body mass index. For status of job, number of working hours per week, working posture, physically strenous work, and job strain no relevant confounders were identified. †Job strain categories: relaxed, low demands and high control; passive, low demands and low control; active, high demands and high control; strained, high demands and low control.

case group. Odds ratios (OR) are presented as crude estimates and adjusted estimates. In the final model the exposure variables under study were mutually adjusted and also adjusted for relevant confounders. Selection of which confounders to include was based on the change in estimates principle. All putative confounders were included in the model, and if one factor when removed changed the estimates more than 5\% this variable was kept in the model. Tests for interaction between job strain and social support and between job strain and physical working conditions were performed using the likelihood ratio test statistic. Analyses were carried out using SPSS 10.0 software.

\section{RESULTS}

During recruitment to the case-control study $16 \%$ of the women reported pelvic pain to an extent that affected their ability to walk, and $8 \%$ reported strong pelvic pain according to the severe case definition used in this study (data not shown).

About three quarters of both cases and controls reported that they were working at the time of the first interview or had been working during the previous three months (table 1). Severe cases were slightly more often out of work (289 of $1099=26 \%)$ than mild cases $(114$ of $523=22 \%)$ and controls $(428$ of $1967=22 \%)$.

All the following analyses are restricted to the 1219 cases and 1539 controls who were working at the time of the first interview or had been working within the past three months. Students were included if they worked at least 15 hours per week.

We found that age, pre-pregnant BMI, the prevalence of previous back pain, and psychiatric illnesses had a uniform distribution over exposure categories. Women who had suffered from pelvic pain previously were more likely to hold high status jobs than women with no pelvic pain history. Women who had given birth before were more likely than nullipara to hold jobs of lower status, to carry heavy loads at work, and to work part time. Smoking was more common among women in lower job status groups and among women with strenuous work (data not shown).

Table 2 presents ORs for pelvic pain as a function of physical working conditions and job strain, analysed for the entire case group. Restricting analyses to severe cases did not change the estimates much (data not shown). When we adjusted for all possible confounders (see measurement of exposure section) the estimates were similar to the ones shown in table 2 except for working hours and for carrying of heavy burdens at work, for which reason these exposures were adjusted (see footnote to table 2). Working hours outside fixed daytime were associated with an increased risk of pelvic pain after adjustment for the other job exposures and confounders. The estimates were statistically significant for fixed evening workers (OR 1.76) and rotating shift workers (without night shift) (OR 1.65). Physically strenuous work was associated with an almost 50\% increased risk of pelvic pain (OR 1.47). Women in the high strained or in the active job strain groups were more likely to report pelvic pain than women in the passive or the relaxed groups (OR 1.39 and 1.32 , respectively).

The association between job strain and pelvic pain was not modified by physical working conditions or by social support (data not shown). To form a more homogenous population we restricted data to include health care workers only (243 cases, 228 controls). Pelvic pain ORs adjusted for possible confounders were 3.72 (95\% confidence intervals (CI) 1.74 to 7.99) for rotating shift work without nightshift, 1.83 (1.05 to 3.20) for rotating shift with nightshift, 1.45 (0.87 to 2.40) for physically strenuous work, and 1.01 (0.55 to 1.84$)$ for high 
job strain. We also tried to exclude all students (left were 598 cases, 1216 controls) and found ORs of 1.67 ( 1.21 to 2.31) for rotating shift work without nightshift, 1.44 (1.04 to 1.99) for rotating shift with nightshift, 1.39 (CI 1.08 to 1.79) for physically strenuous work, and 1.31 (1.03 to 1.68) for high job strain.

\section{DISCUSSION}

Pelvic pain was a common problem among women in the Danish national birth cohort. We found rotating shift work, physically strenuous work, and demanding work (high job strain) to be associated with pelvic pain. We found no association with job status, work posture, or carrying of heavy burdens at work.

Our findings on job strain are supported by results from one cross sectional study ${ }^{9}$ and need to be confirmed by others. The same study has reported work posture to be associated with pelvic pain, ${ }^{9}$ which we did not see. This may be attributable to reverse causality in the cross sectional study or simply to random variation. We only found one study that had examined shift work and pelvic pain, and they found no association. ${ }^{11}$

Job strain consists of complex concepts like job demand and job control. According to Karasek a number of items should be included to fully describe the demand dimension: workload, time available, speed, and exertion. We believe, however, that these features partly are reflected in the answer to the question: "do you have too much to do when at work?". The control variable used in this study ("do you have influence on your working conditions?") reflects to a larger extent decision authority and to a smaller extent skill discretion, which was not measured. Both decision authority and skill discretion are described to be part of the control dimension.

It was never expected that the birth cohort would provide a representative sample of pregnant women in Denmark. We have, however, sufficient variation in the exposure status to perform meaningful comparisons. Selection bias could explain the associations found if the decision to take part in the birth cohort study was based upon both working conditions and pelvic pain. This type of bias is unlikely because recruitment to the birth cohort took place before the onset of pelvic pain.

Confounding could also explain the associations found between work related risk factors and pelvic pain. Only little is known about the causes of pelvic pain, and therefore we do not know if we have adjusted for all other determinants that correlate with exposure. The fact that demographic factors (age, parity) and lifestyle factors (smoking, body mass index) did not confound the association, speaks against strong confounding (body mass index confounded carrying of heavy burdens only). However, body mass index was based upon self reported data on weight, which is known to be underestimated among overweight women, and therefore residual confounding may exist.

A number of 549 women who answered yes to the screening question subsequently reported pain outside the

\section{What this paper adds}

This study within the Danish national birth cohort finds that psychosocially demanding work environment and some measures of physically demanding work are associated with an increased risk of pelvic pain in pregnancy. The study contributes to the elucidation of methodological difficulties in handling those types of diseases and syndromes that are predominantly based on subjective pain reporting. pelvic area. These women were excluded from further analysis, as were 115 controls who reported pain equivalent to the severe case group in the following questions on pain intensity. We did not include the 549 potential cases in the control group and we excluded the 115 potential controls because we wanted to identify a control group who clearly did not have pain. We did not add the 115 to the case group afterwards because this would break the sampling design of the study and could result in a less distinct case group.

The fact that $6 \%$ of the initially selected controls fulfilled the criterion for strong pain in daily functions and $40 \%$ fulfilled the criterion for mild pain, although they did not say yes to the screening question, may suggest that pelvic pain or pain similar to pelvic pain is common during pregnancy and that pelvic pain may just represent the tail of a distribution rather than a distinct entity.

We tried to limit the study to more homogenous groups to better adjust for social confounding. Excluding students showed similar estimates as the ones found for all. When restricting data to health care workers only we found a notably increased risk in women working in rotating shift without nightshift, pointing to some interaction between working hours and working sphere. Estimates were adjusted for previous pelvic pain, so the explanation could not be that women with previous pelvic pain are spared night work when pregnant again. However, it may be that women are spared night work for other reasons that could be related to pelvic pain.

Outcome data were based upon self reported pelvic pain. Measuring pelvic pain has to be based upon self reports from the women as an "objective" clinical test in any case has to be "validated" with reference to symptoms. ${ }^{8}$ This is not different from most other pain related diseases like headache or lower back pain. It may be argued that clinical examination is necessary to diagnose pelvic pain. The aim of this study was to explore possible associations related to pelvic pain in pregnancy, as reported by the women, more than stating the incidence of the condition. As subjective symptoms of pelvic pain correlate well with results of clinical tests we should be able to capture an association with this study design. ${ }^{8}$

We recorded pelvic pain six months after delivery, which may cause some underreporting of milder cases of shorter duration. For studies to be comparable a similar end point registration is needed. We tried to get comparable data from all participants in the study. All interviewers underwent the same training programme before interviewing, and they had the same explanatory text available on their computers, in lay and medical terms, when interviewing.

As job situation changes rapidly over time and as health selection to the workforce depends upon the level of unemployment and general social conditions, one cannot expect any large agreement between different studies from different populations or different time periods. Standardised job descriptions will not solve this "healthy worker selection" problem. The good possibilities in Denmark for pregnant women to be taken out of the workforce and receive an economic compensation are expected to attenuate the associations we studied. We are only able to identify causal links that have not been eliminated by medical or social interventions.

The strengths of this study are its size, the fact that exposure data are collected prospectively and in a population with a high incidence of pelvic pain, and the good quality of data on exposures and confounding factors. The weaknesses are mainly related to the lack of an objective test for pelvic pain and the fact that pelvic pain was measured six months after delivery.

If the associations are not spurious they may operate on biological or psychological mechanisms and they may involve 
intermediate factors, which we have not recorded. Regardless of these mechanisms; if the associations are causal the incidence of pelvic pain should go down if the causes are removed.

This study includes only women who were or had been working during the actual pregnancy, and as no interviews were performed earlier than pregnancy week 12, all work exposure was measured within pregnancy. The risk factors we study are all avoidable, especially for a short time period of nine months. Pregnant women can be placed at work that does not entail physically strenuous work, rotating shifts, and high job strain.

In conclusion, we found that both physically and psychosocially demanding working conditions, measured by physically strenuous work, rotating shifts, and high job strain, are associated with an increased reporting of pelvic pain in pregnancy.

\section{ACKNOWLEDGEMENTS}

The Danish National Research Foundation has established the Danish Epidemiology Science Centre that initiated and created the Danish national birth cohort. The cohort is furthermore a result of a major grant from this foundation. Additional support for the Danish National Birth Cohort is obtained from the Pharmacy Foundation, the Egmont Foundation, the March of Dimes Birth Defects Foundation, and the Augustinus Foundation.

\section{Authors' affiliations}

M Juhl, National Institute of Public Health, Denmark

P K Andersen, Institute of Public Health, Department of Biostatistics, University of Copenhagen, Denmark

J Olsen, Danish Epidemiology Science Centre at the Department of Epidemiology and Social Medicine, University of Aarhus, Denmark and Department of Epidemiology, School of Public Health, UCLA, LA, USA A-M N Andersen, National Institute of Public Health, Denmark, and Institute of Public Health, Department of Social Medicine, University of Copenhagen, Denmark

Funding: this specific study was supported by grants from The Health Insurance Foundation in Denmark. The Health Insurance Foundation supported the study financially and had no role in any other parts of the study.

Competing interests: none declared.

Ethics approval: the Danish national birth cohort and the case-control study on pelvic pain have been approved by the committee for biomedical research ethics in the municipalities of Copenhagen and Frederiksberg on behalf of all ethic committees in the country, and by the Danish Data Protection Agency.

\section{REFERENCES}

1 Lindenskov L, Kristensen FB, Andersen AMN, et al. Forebyggende helbredsundersøgelser af gravide kvinder i Danmark: Almindelige helbredsgener i svangerskabet [Common ailments in pregnancy reported in connection with prenatal visits in Denmark]. Ugeskr Laeger 1994; 156:2897-901

2 Hansen A, Jensen DV, Wormslev $M$, et al. Symptom-giving pelvic girdle relaxation in pregnancy. II: Symptoms and clinical signs, Acta Obstet Gynecol Scand 1999;78:111-15.

3 Moen MH, Tingulstad S. Bekkenledssyndromet som årsak til kroniske underlivssmerter [Chronic pelvic pain caused by the pelvic joint syndrome]. Tidsskr Nor Laegeforen 1991;111:690-701.

4 Wormslev M, Juul AM, Marques B, et al. Clinical examination of pelvic insuffiency during pregnancy. An evaluation of the interobserver variation, the relation between clinical signs and pain and the relation between clinical signs and physical disability. Scand J Rheumatol 1994;23:96-102.

5 Dietrichs E, Kogstad O. "Pelvic girdle relaxation" - suggested new nomenclature. Scand J Rheumatol Suppl 1991;88:3.

6 Kogstad O, Biornstad N. Bekkenløsning. Patogenese/etiologi/definisjon/ epidemiologi [Pelvic girdle relaxation. Pathogenesis, etiology, definition, epidemiology]. Tidsskr Nor Laegeforen 1990;110:2209-11.

7 Østergaard M, Bonde B, Thomsen BS. Insufficientia pelvis in graviditate. Ugeskr Laeger 1992;154:3568-72.

8 Albert H, Godskesen M, Westergaard J. Evaluation of clinical tests used in classification procedures in pregnancy-related pelvic joint pain. Eur Spine J 2000;9:161-6.

9 Endresen EH. Pelvic pain and low back pain in pregnant women-an epidemiological study. Scand J Rheumatol 1995;24:135-41.

10 Heiberg E, Stray-Pederson B. Bekkensmerter i svangerskapet. Et belastningssyndrom? [Pelvic pain in pregnancy. A strain syndrome?author's translation]. Norsk Epidemiologi 1997;7:117-21.

11 Larsen EC, Wilken-Jensen C, Hansen A, et al. Symptom-giving pelvic girdle relaxation in pregnancy. I: Prevalence and risk factors, Acta Obstet Gynecol Scand 1999;78:105-10.

12 Skov R. Forløbet af bækkenløsning hos 40 gravide [The course of pelvic girdle relaxation in 40 pregnant women-author's translation]. Manedsskr Prakt Laegegern 1988;66:415-19.

13 Östgaard HC. Assesment and treatment of low back pain in working pregnant women. Semin Perinatol 1996;20:61-9.

14 Berezin D. Pelvic insuffiency during pregnancy and after parturition. The clinic of pelvic insufficiency. Acta Obstet Gynecol Scand 1954;33:89-92.

15 Endresen EH. Bekkenløsning-en tilstand med mange navne og uklare kriterier [Pelvic pain during pregnancy-a condition with many names and ambiguously defined?]. Tidsskr Nor Laegeforen 1995;1 15:3271-3.

16 Mens J, Vlemming A, Støckart R, et al. Understanding peripartum pelvic pain. Implications of a patient survey. Spine 1996;21:1363-70.

17 Albert H, Godskesen M, Westergaard J. Prognosis in four syndromes of pregnancy-related pelvic pain. Acta Obstet Gynecol Scand 2001;80:505-10.

18 Rasmussen OB, Sorensen AU, Nielsen CV. Sygemelding af gravide i Fjends Kommune 1987-1990 [Sick leave of pregnant women in the municipality of Fiend 1987-1990]. Ugeskr Laeger 1996;158:7069-73.

19 Tophøj A, Sabroe S. Orlovsvarighed og fraværsmeldinger i graviditeten [Duration of maternity leave and absence incidences due to pregnancyauthor's translation]. Ugeskr Laeger 1999;161:5014-19.

20 Voigt S. Sygemelding under graviditet. Omfang, diagnosemønster og sygemeldende instans [Sick-listing in pregnancy. Extent, diagnostic pattern and the issuing authority]. Ugeskr Laeger 1993;155:86-9.

21 Albert H, Godskesen M, Westergaard JG, et al. Circulating levels of relaxin are normal in pregnant women with pelvic pain. Eur J Obstet Gynecol Reprod Biol 1997;74:19-22.

22 Bjorklund K, Bergstrom S, Nordstrom ML, et al. Symphyseal distention in relation to serum relaxin levels and pelvic pain in pregnancy. Acta Obstet Gynecol Scand 2000;79:269-75.

23 Hansen A, Jensen DV, Larsen E, et al. Relaxin is not related to symptom-giving pelvic girdle relaxation in pregnant women. Acta Obstet Gynecol Scand 1996;75:245-9.

24 Kristiansson P, Svardsudd K, von Schoultz B. Serum relaxin, symphyseal pain, and back pain during pregnancy. Am J Obstet Gynecol 1996;175:1342-7.

25 Petersen LK, Hvidman L, Uldbjerg N. Normal serum relaxin in women with disabling pelvic pain during pregnancy. Gynecol Obstet Invest 1994:38:21-3.

26 Bïrrklund K, Bergström S. Is pelvic pain in pregnancy a welfare complaint? Acta Obstet Gynecol Scand 2000;79:24-30

27 Hoogendoorn WE, Bongers PM, de Vet HC, et al. Psychosocial work characteristics and psychological strain in relation to low-back pain. Scand J Work Environ Health 2001 ; 27:258-67.

28 Joksimovic L, Starke D, Knesebeck O, et al. Perceived work stress, overcommitment, and self-reported musculoskeletal pain: a cross-sectional investigation. Int J Behav Med 2002;9:122-38.

29 MacDonald LA, Karasek RA, Punnett L, et al. Covariation between workplace physical and psychosocial stressors: evidence and implications for occupational health research and prevention. Ergonomics $2001 ; 44: 696-718$.

30 Rolander B, Bellner AL. Experience of musculo-skeletal disorders, intensity of pain, and general conditions in work - the case of employees in non-private dental clinics in a county in southern Sweden. Work 2001;17:65-73.

31 Karasek RA. Job demands, job decision latitude, and mental strain: implications for job redesign. Admin Sci Q 1979;24:285-308.

32 Schnall PL, Landsbergis PA, Baker D. Job strain and cardiovascular disease. Annu Rev Public Health 1994:15:381-411.

33 Olsen J, Melbye M, Olsen SF, et al. The Danish national birth cohort-its background, structure and aim. Scand J Public Health 2001;29:300-7. 